\title{
Salud en la adversidad: un resumen de la historia sanitaria del Brasil
}

\section{Health in adversity: a summary of the history of healthcare in Brazil}

\author{
Marcos Cueto \\ Pesquisador visitante da Casa de Oswaldo Cruz/Fundação Oswaldo Cruz; \\ professor da Universidad Peruana Cayetano Heredia. \\ marcoscueto@fiocruz.br
}

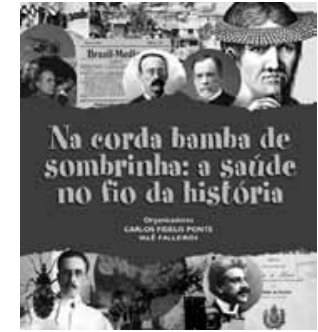

PONTE, Carlos Fidelis; FALLEIROS, lalê (Org.). Na corda bamba de sombrinha: a saúde no fio da história. Rio de Janeiro: Casa de Oswaldo Cruz e Escola Politécnica de Saúde Joaquim Venâncio/Fiocruz, 2010. $337 p$.

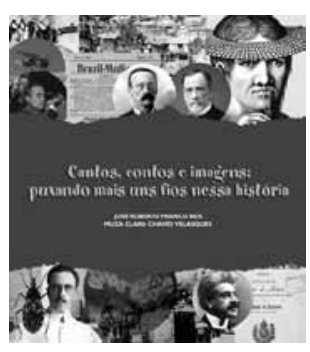

REIS, José Roberto Franco; VELASQUES, Muza Clara Chaves. Cantos, contos e imagens: puxando mais uns fios nessa história. Rio de Janeiro: Casa de Oswaldo Cruz e Escola Politécnica de Saúde Joaquim Venâncio/Fiocruz, 2010. 96p.
$\mathrm{L}$ os historiadores de la salud de América Latina en general y de Brasil en particular han realizado valiosas contribuciones en su campo de estudios durante los últimos años. Sin embargo, pocas veces se han concentrado en producir textos novedosos, claros y profundos que cautiven por su contenido e imágenes a un público amplio; es decir, a lectores no especializados en la historia. Esto lo consiguen los organizadores y autores de estos dos libros de difusión quienes articulan una narración didáctica e intrigante en apenas diez capítulos en cada uno de los dos libros. Ambos textos fueron auspiciados por el Observatório História e Saúde (de la Casa de Oswaldo Cruz de Fiocruz) y por el Observatório dos Técnicos em Saúde (de la Escola Politécnica de Saúde Joaquim Venâncio, también de Fiocruz) y realizados en su mayoría por investigadores de la Casa. La Organización Panamericana de la Salud y el Ministerio de Salud del Brasil fueron otras instituciones que además hicieron posible su realización.

Antes que nada quiero resaltar un asunto que puede parecer secundario. Es espectacular el inteligente uso de imágenes. Algo inusual para un libro de historia. Los textos están atravesados por retratos, afiches, mapas, titulares de periódicos, fotos de laboratorios y de edificios, cortes histológicos, recetas médicas, carátulas de libros y de revistas, así como grabados, caricaturas y pinturas que aparecen en casi cada otra página. Aunque muchas ya habían sido usadas antes en otras publicaciones, algunas son, o parecen ser, inéditas. Las leyendas que las acompañan explican el significado y origen de cada imagen. Las citas son reducidas a lo esencial - algunas provienen de archivos - y cumplen su deber de certificar y acompañar la lectura; aunque las hay repetitivas y la publicación se hubiera beneficiado de una sola bibliografía general. A pesar de ser una obra realizada por varios autores, los organizadores lograron disminuir la duplicación de temas y controlar el desorden que genera un texto escrito a varias manos. Todo un logro. 
El principio organizador del primer libro es la peripecia de los trabajadores de salud por obtener mejores condiciones de vida en el Brasil, contextualizando su labor en un marco internacional. El primer libro describe la conformación de un campo de saberes y prácticas inter-disciplinarias que se retroalimentaba e influía en el devenir social y político del país. Dos premisas más recorren este texto inicial. La primera señala que la salud pública se ha desarrollado en medio de vicisitudes adversas y complejas - como el equilibrista de un circo que atraviesa una cuerda floja que pende a varios metros de altura de la tierra - pero que logró ganarse un importante espacio en el quehacer del Estado y concentrar la labor de un importante número de profesionales. Un segundo supuesto afirma que la formación de la ciudadanía brasilera es parte de tres procesos: el reconocimiento de la salud como un derecho de las personas, la inscripción de la medicina en la cultura nacional y la construcción de las políticas sociales del Estado.

Aunque el énfasis es el siglo XX, esta obra se inicia con una visión panorámica del saber y poder médico en el Brasil imperial que se remonta a comienzos del periodo colonial. Este capítulo indaga sobre creencias y expectativas que parecen antiguas pero que a veces tienen vigencia hasta el día de hoy como la búsqueda de la armonía entre el cuerpo, la mente y la naturaleza. Una sugerencia importante del primer capítulo es que la coexistencia entre diversos sistemas médicos (como el indígena, el africano y el occidental) permitía la tolerancia y desalentaba rígidas jerarquías entre sus practicantes.

El segundo capítulo resume con habilidad la llegada de la bacteriología y la teoría del germen de la enfermedad, poniendo énfasis en los procesos de recepción, validación mundial de descubrimientos locales y de circulación internacional de científicos en un período en que el país iniciaba su impulso modernizador e imitaba la cultura europea al compás de aires republicanos oligárquicos y de una economía de exportación de materias primas.

Un tercer y fascinante capítulo lidia con el redescubrimiento del interior del país por las expediciones de los sanitaristas, algo que ciertamente ocurrió en muchos países latinoamericanos de comienzos del siglo XX, pero que ha sido estudiado con mayor intensidad en el caso de esta nación. En ese momento, el médico Miguel Pereira pronunció la celebra frase "Brasil es un inmenso hospital". Los sanitaristas tuvieron una contribución fundamental en la emergencia de proyectos nacionales más solidarios, pero que también marginalizaron a los más pobres, creando estereotipos como el del campesino enfermo que supuestamente sería redimido por la medicina. Este capítulo tiene una sección sobre los estudios y actividades de control de la enfermedad de Chagas, así como de su inscripción en el movimiento sanitarista de comienzos de siglo que resume y trae nuevas perspectivas a un tema crucial y clásico de la historia brasilera.

Posteriormente, el capítulo cuatro trata de la agenda sanitaria en propuestas nacionalistas, populistas y autoritarias. Entonces, se debatió el papel que tendrían los funcionarios de salud en el desarrollo - especialmente cuando se crea el Ministerio de Salud en 1953 - y en las verdaderas motivaciones del presidente Getúlio Vargas que dominó la política brasilera a mediados del siglo XX. Un capítulo no menos importante es el de Brasil de la postguerra cuando surgen en el mundo poderosas agencias bilaterales y multilaterales junto a los ideales de un Estado de Bienestar. Este es seguido por otro capítulo de los duros años de la dictadura militar, que se inicio en 1964 y permaneció en el poder aproximadamente dos décadas, cuando 
la salud, como dice Ponte, fue "un derecho de pocos". A pesar de todo, Brasil consiguió éxitos notables en inmunizaciones de enfermedades prevenibles y exportó no solo sus productos biológicos sino parte de sus trabajadores de salud.

Una sección final trata de la contribución de los trabajadores de salud a la democratización del país, a mediados de los años ochenta, y a la catalización de un movimiento social a favor de la reforma sanitaria expresada en la revista Saúde em Debate en la noción 'saúde coletiva' y en la Octava Conferencia Nacional de Salud, realizada en 1986. Estos eventos fueron clave para la confirmación de lo que se trata en el siguiente capítulo: el surgimiento de un modelo universal, equitativo, descentralizado y que rompía las diferencias artificiales entre rehabilitación, prevención y tratamiento que buscó materializarse en el SUS (Sistema Único de Saúde).

Los dos últimos artículos llevan, con coherencia, la historia a una discusión contemporánea. Los capítulos penúltimo y último sugieren que lo ocurrido en la década del noventa, es decir la globalización, privatización de los servicios públicos y liderazgo de propuestas neoliberales e intervencionistas del Banco Mundial, afectaron la efectividad e integralidad del sistema de salud, precarizaron la estabilidad y los recursos de los trabajadores de salud y debilitaron la promesa del SUS.

El segundo libro es básicamente un material pedagógico de apoyo al primero. Sigue el orden de los capítulos y está orientado a quienes quieran profundizar más en algunos temas. Es lo que en Brasil se llama "encarte", dirigido a estudiantes universitarios y profesores para que estos últimos lo utilicen como una guía. Hace que la historia sea una herramienta crítica para pensar el presente y proyectar el futuro y para contribuir a la formación de los funcionarios sanitarios. Entre los materiales presentados en este segundo texto se encuentran, además de referencias a lecturas y a películas, indicaciones de sambas, canciones populares, obras literarias, sites de internet, más imágenes y hasta citas de poesías relacionadas con la historia de la salud.

Esta segunda publicación no fue realizada bajo el supuesto que el alumno debía informarse de acontecimientos ocurridos racionalmente ni que el diseño de las ideas y las imágenes es un asunto secundario. También va en contramano de los historiadores que prejuiciosamente consideran los resúmenes como una simplificación de nociones complejas. Tanto la guía como el primer libro, dejan la sensación, y no solo la idea, de que la salud física y mental así como el trabajo sanitario hecho desde dentro y fuera del Estado ha sido parte de la cultura de Brasil. Además las interpretaciones consiguen develar y cuestionar los temas que trata, estimular una mirada crítica a la salud pública y utilizar la estética en un texto literalmente iluminado de colores, nociones y formas para promover la creatividad. Esta obra en conjunto nos ayuda a comprender con imágenes, a imaginar a través de textos, y a sentir las ideas. No menos importante es el DVD que acompaña al primero de los libros reseñados.

¿Podría realizarse algo parecido para otros países de América Latina? O quizás, ¿para la región entera? ¿Por qué no? 